\title{
Pengendalian Iklim Pasif di Museum Sebagai Antisipasi Perubahan Iklim
}

\author{
Ita Yulita \\ Museum Nasional Jakarta \\ Email : itayulitas@gmail.com
}

\begin{abstract}
Abstrak: Perubahan iklim (dimatedhang) akhir-akhir ini menjadi banyak perhatian. Hampir di segala bidang di antaranya kesehatan, peternakan, transportasi, komunikasi, pendidikan, kelautan hingga budaya membicarakan perubahan iklim dan dampaknya terhadap masing-masing. Semua mempersiapkan diri, mencoba melakukan tindakan preventif untuk menjaga agar tetap bertahan dari serangan dampak negatif perubahan iklim. Perubahan iklim yang dimaksud tersebut adalah perubahan iklim akibat pemanasan global, yang merubah iklim di dunia secara signifikan.

Namun sebenarnya di bidang budaya, terutama di museum, perubahan iklim sudah terjadi sejak lama, namun sering tidak disadari, bahkan oleh pekerja di museum sendiri. Perubahan iklim tersebut tidak secara langsung berhubungan dengan isu pemanasan global yang ramai dibicarakan, tetapi apabila tidak diantisipasi akan berdampak negatif pada koleksi. Tulisan ini menguraikan bagaimana perubahan iklim di museum, bagaimana efeknya dan bagaimana mengatasi dampak perubahan iklim tersebut pada koleksi museum, melalui pengendalian iklim pasif padakoleksi.
\end{abstract}

Kata Kunci : Perubahan iklim, iklim pasif, koleksi museum

\begin{abstract}
Recently, the climate change has been as the most important issue. Almost in all fields, such as health, lifestock, transportation, education, maritime, until culture has been talking about climate change and it's effect. All fields prepare and try to prevent the negative effect of climate change. This Climate change means changing climate caused by the global warmingissue.

In Museum, the climate change has been happening since a long time ago, indeed. But it is almost not realized, even for museum staffs. It is not related with global warming issue directly, but if it is not handled properly, the museum's collection will getting worst. This article try to describe how the climate change in museum and its effect, also how to minimize negative effect to museum's collections by passive climate control.
\end{abstract}

Keywords : climate change, passiveclimate, museum's collections

\section{A. Pendahuluan}

Museum merupakan tempat pelestarian koleksi yang dapat berasal dari mana saja, selama koleksi tersebut memiliki nilai historis yang tinggi dan layak sebagai koleksi. Jika dilihat dari asal lokasi temuan, koleksi museum dapat berasal dari situs di permukaan tanah (candi, komponen candi, komponen bangunan, komponen tempat ibadah), dari situs di dalam tanah (yang terkubur lalu di gali dan diangkat ke permukaan), dari bawah permukaan laut, danau, sungai dan juga dapat berasal dari dalam gua. Selain berasal dari temuan situs, koleksi museum dapat berasal dari pengrajin yang berasal dari daerah-daerah tertentu, karena mewakili kebudayaan etnik tertentu. Bahkan, koleksi bisa berasal dari pemberian, hadiah atau hibah seseorang yang ternama selain itu juga dari pembelian jika memang diperlukan.

Apabila sebuah objek terpilih menjadi koleksi museum, sebenarnya telah terjadi perubahan iklim pada koleksi, dari iklim asli (asal koleksi) menjadi iklim museum. Dari iklim lingkungan makro menjadi iklim lingkungan mikro. Selain itu, jika di dalam museum terjadi perpindahan (relokasi) koleksi dari gedung satu ke gedung yang lain akan terjadi pula perubahan iklim pada koleksi, terutama jika kedua gedung tersebut memiliki karakteristik yang berbeda.

Sifat gedung sangat mempengaruhi keadaan iklim di dalam ruangan, karena gedung merupakan pembatas / barier antara lingkungan di luar dan di dalam. Sayangnya perubahan iklim yang dialami oleh koleksi ini sering tidak diperhatikan, bahkan oleh pengelola museum sendiri. Padahal, perubahan iklim ini tanpa disadari merupakan pencetus awal kerusakan dan penurunan mutu koleksi. Perubahan iklim akan memberikan dampak yang bersifat kumulatif dan negatif pada koleksi, sebaiknya menjadi perhatian para pengelola museum. 


\section{B. Permasalahan}

Adanya perubahan iklim yang tidak disadari pengelola koleksi dapat menimbulkan permasalahan baru. Akan tetapi masalah tersebut baru terlihat setelah beberapa lama. Permasalahan akibat perubahan iklim, yaitu perubahan temperatur dan kelembaban relatif dari tempat asal ke tempat yang baru, antara lain:

- Pertumbuhan jamur pada koleksi, penyangga, dan vitrin;

- Pemicu munculnya serangga;

- Kerusakan fisik pada koleksi,

Dikarenakan benda cagar budaya yang sudah berada di dalam museum merupakan benda yang memiliki nilai historis tinggi, sudah sewajarnya permasalahan yang terlihat sederhana seperti disampaikan diatas segera diantisipasi.

\section{Pembahasan}

Perubahan iklim yang dibahas adalah perubahan temperatur ( $\mathrm{T}$ ) dan perubahan kelembaban relatif $(\mathrm{RH})$ yang melingkupi koleksi. Kedua faktor tersebut merupakan bagian dari sepuluh (10) faktor/agen yang menyebabkan kerusakan pada koleksi. Kesepuluh agen tersebut adalah : (1) gaya fisik; (2) pencurian dan vandalisme; (3) dissosiasi, (4) api, (5) air, (6) hama, (7) polutan, (8) cahaya, Ultra Violet dan Infra merah; (9) temperatur tidak sesuai dan (10) kelembaban relatif (RH) tidak sesuai (Grattan 2011).

Museum didefinisikan sebagai tempat berlindungnya koleksi dari serangan agen penyebab kerusakan. Hal ini berarti bahwa museum dan gedung museum (tempat menyimpan koleksi) berfungsi melindungi koleksi terhadap 10 agen kerusakan/deteriorasi. Yulita (2008:55) mengutip Pedersoli (2007) menjelaskan bahwa lingkungan museum apabila dibuat penampang melintang akan terlihat seperti kotak di dalam kotak (box in the box). Koleksi museum ditempatkan dalam wadah atau penyangga yang berada di dalam tempat penyimpanan, dan ini merupakan kotak terdalam. Tempat koleksi ini berada di dalam vitrin/showcase yang berada di dalam sebuah ruangan pajang atau ruang simpan. Ruangan simpan/ruang pajang merupakan bagian dari gedung. Gedung museum merupakan bagian dari lokasi dimana museum itu berada, dan merupakan bagian dari kota, pulau, hingga negara. Sebaliknya, jika memandang lingkungan yang melingkupi koleksi museum mulai dari terluar hingga ke dalam adalah:

Daerah--situs/lokasi--gedung--ruangan-vitrin-penyangga koleksi (Gambar 1)

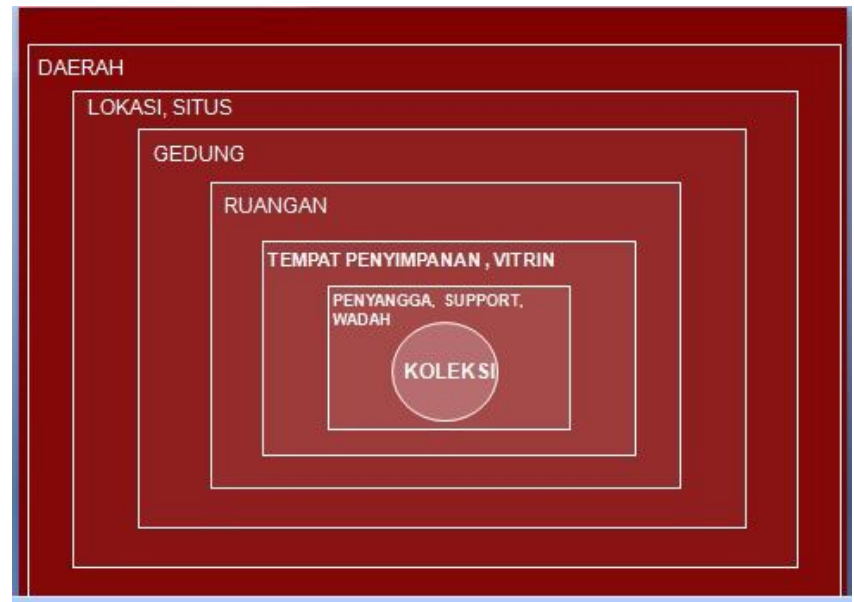

Gambar 1. Bagan lingkungan disekitar koleksi (Yulita:2008)

Pembatas antara lingkungan luar (makro) dan lingkungan dalam (mikro) dalam museum adalah gedung museum. Berbeda dengan lingkungan makro yang tidak dapat dikendalikan, lingkungan mikro dapat dikendalikan, tentunya dengan menempatkan gedung sebagai pengendali. Gedung museum yang baik dapat mengendalikan iklim mikro di dalamnya dengan menerapkan iklim pasif (pasive climate) di seluruh gedung museum. Iklim pasif ini tercipta jika material gedung yang digunakan sudah mengakomodir pertukaran aliran udara di dalam dan di luar museum (Padfield, 2008).

Permasalahannya, sebagian besar gedung museum yang ada belum dibangun sesuai dengan kaidah-kaidah yang dibutuhkan sebagai pengontrol iklim pasif (Passive climate control), walaupun pengendali iklim pasif sangat diperlukan. Atas dasar hal tersebut, ruang lingkup lingkungan mikro koleksi diperkecil lagi ke ruangan. Jika ini pun sulit, maka ruang lingkup lingkungan mikro adalah vitrin atau tempat dimana koleksi disimpan. Lingkungan mikro yang dikendalikan sebagai iklim pasif disesuaikan dengan material dan kondisi koleksi, karena akan membantu perlindungan dan pemeliharaan koleksi jangka panjang, terutama untuk koleksi yang sebelumnya berasal dari lingkungan yang berbeda, seperti koleksi temuan arkeologi.

Lingkungan mikro dapat diatur sehingga dapat mengantisipasi perubahan iklim. Sebagai gambaran terjadinya perubahan lingkungan pada koleksi dapat dijelaskan pada Gambar 2 yang merupakan grafik deteriorasi (penurunan mutu) koleksi terhadap waktu. Pada grafik tersebut terlihat saat objek (koleksi) dibuat, kondisinya adalah yang terbaik dan nilai deteriorasinya nol, makin lama maka deteriorasi akan semakin besar, meski pada beberapa keadaan terjadi kesetimbangan, yang berarti adalah deteriorasi agak melambat. Misalnya pada kerusakan sebilah keris perunggu yang dibuat oleh empu 


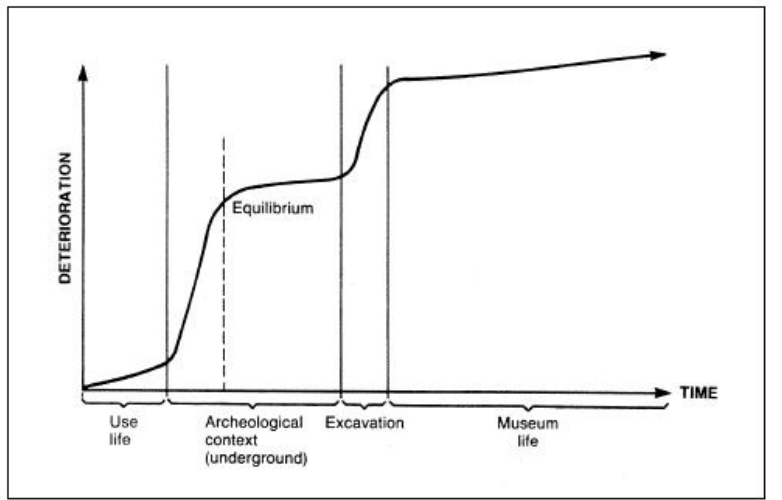

Gambar 2. Grafik deteriorasi koleksi terhadap waktu (sumber Murdock 2001)

atas permintaan tumenggung dimasa kerajaan masih berjaya. Seiring dengan waktu, karena sering dimanfaatkan, akhirnya keris tersebut rusak dan dibuang oleh tumenggung. Keris yang sudah terbuang tersebut, lama kelamaan terkubur di dalam tanah. Saat mulai terkubur (berarti telah terjadi perubahan iklim) proses deteriorasi dan kerusakan pada keris terjadi sangat cepat. Terlihat pada grafik, kurva deteriorasi naik dengan tajam. Hingga suatu saat terjadi kesetimbangan, saat materi keris sudah mengalami keseimbangan dengan iklim di dalam tanah. Proses oksidasi yang terjadi sudah mulai membentuk lapisan korosi yang justru melindungi, dikenal dengan istilah patina. Pada kondisi ini deteriorasi melambat, keris sudah beradaptasi dengan lingkungannya.

Ketika arkeolog datang dan memutuskan untuk melakukan ekskavasi di daerah tersebut karena diyakini banyak temuan, maka lapisan tanah terbuka, dan menemukan keris yang selama ini terkubur. Iklim yang mengenai koleksi berubah drastis. Koleksi yang sebelumnya sudah beradaptasi akan mengalami kondisi yang ekstrim karena terjadi perubahan iklim yang cepat. Akibatnya kurva deteriorasi akan naik dengan tajam, menunjukkan adanya perubahan yang sangat cepat pada koleksi.

Langkah berikutnya, arkeolog memutuskan untuk menyimpan keris temuan ke dalam museum. Saat dibawa ke museum, kembali terjadi perubahan iklim. Koleksi akan mulai bereaksi dan beradaptasi dengan lingkungannya yang baru. Dimana sebelumnya berada di bawah permukaan tanah, masuk kedalam gedung yang iklimnya jauh berbeda. Koleksi akan kembali beradaptasi dengan lingkungan barunya (museum). Diharapkan kurva deteriorasi kembali landai. Dan diharapkan selama di museum terjadi kesetimbangan baru seperti di dalam tanah. Kesetimbangan yang baru berarti koleksi sudah beradaptasi dengan lingkungannya, dan tidak terjadi deteriorasi yang menukik tajam. Jika terjadi seperti ini berartigedung museum sudah menjalankan tugas sebagai barier dari lingkungan luar.

Kasus berikutnya yang dapat ditampilkan adalah perubahan iklim yang dialami koleksi akibat relokasi dari gedung satu ke gedung yang lainnya, terutama jika kondisi gedung berbeda dengan gedung sebelumnya. Koleksi yang sebelumnya sudah beradaptasi, karena terjadi perubahan iklim akan mengalami deteriorasi kembali. Kondisi ini yang sering terjadi pada banyak museum, termasuk di Indonesia. Sebagai contoh permasalahan yang timbul akibat adanya perubahan iklim ini adalah kajian awal iklim pada ruang pamer gedung B Museum Nasional.

Museum Nasional Indonesia (MNI) memiliki gedung dan ruang pamer baru. Sejak tahun 2006 sejumlah koleksi dipindah dari ruang pamer di gedung lama (gedung A) ke ruang pamer di gedung baru (gedung B). Sebagai informasi, gedung lama adalah gedung dari abad ke-19, beratap tinggi dan terdapat ventilasi dan kipas angin. Gedung ini menggunakan AC, namun hanya pada beberapa tempat saja. Kondisi yang digambarkan ini adalah kondisi ruang pamer gedung lama sebelum dilakukan program revitalisasi museum tahun 2010. Adapun gedung baru adalah gedung yang terletak disebelahnya, terdiri atas 7 lantai yang dilengkapi dengan AC, yang beroperasi pada siang hari, jam kerja dan dimatikan pada waktu malam hari. Sifat gedung tertutup dan tidak terdapat ventilasi, khususnya di ruang pamer koleksi yang berada di lantai 1,2,3 dan 4. Udara bergerak dapat diperoleh dari lantai 1 hingga lantai 3 di bagian foyer eskalator.

Saat dilakukan monitoring pada koleksi oleh tim konservasi diruang pamer lantai 3 ditemukan kondisi berikut:

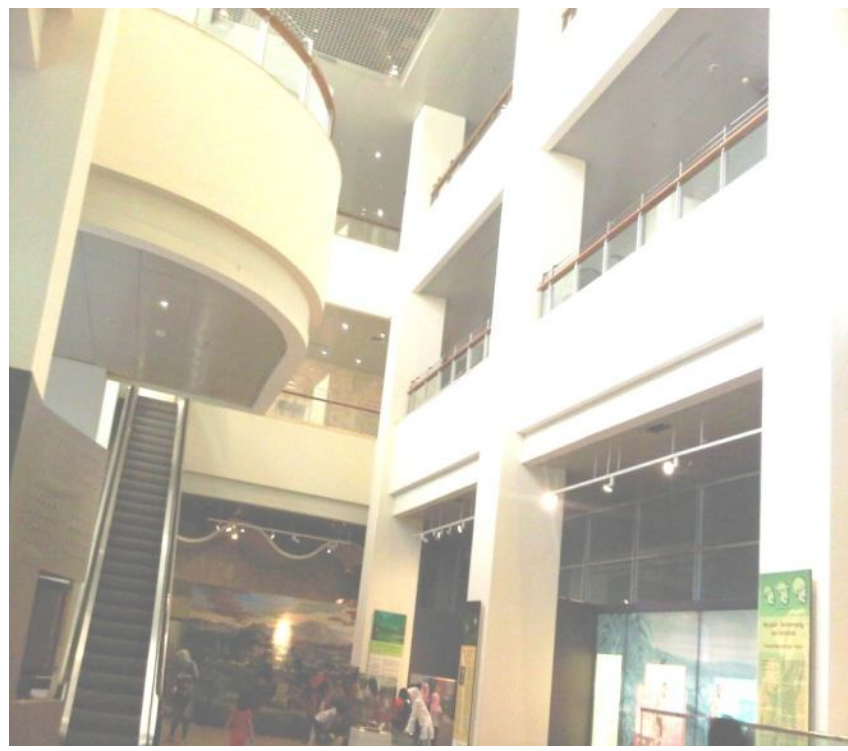

Gambar 3. Ruangan di gedung baru (gedung B ) Museum Nasional 

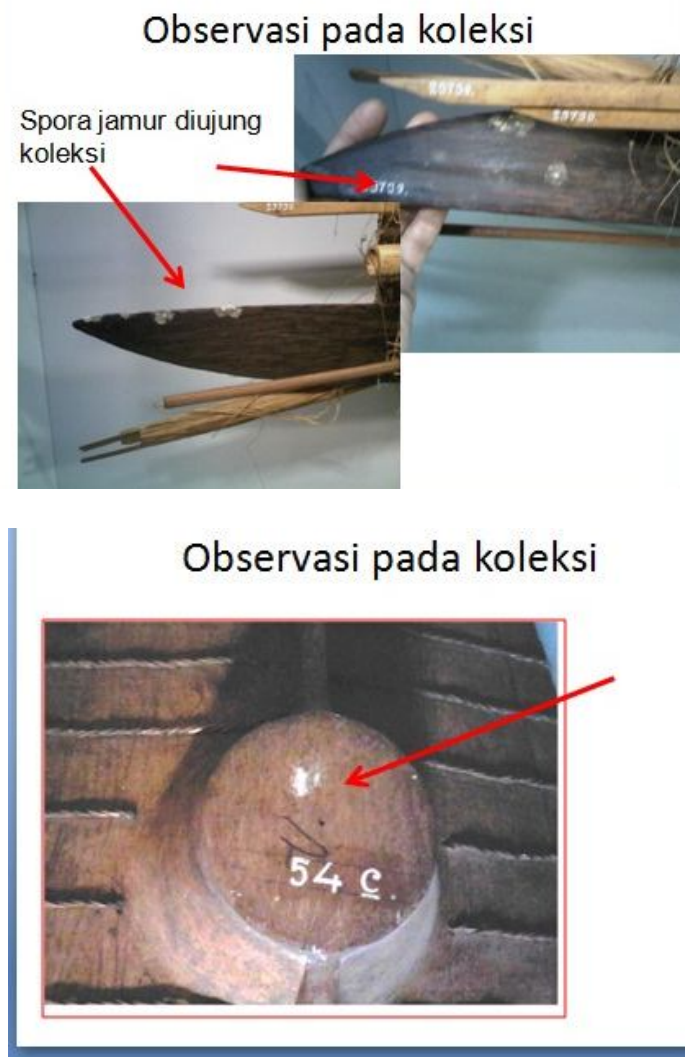

Gambar 4. Koleksi ditumbuhi jamur pada permukaan (foto: koleksi pribadi)

- Beberapa koleksi ditumbuhi jamur pada permukaan

- Ditemukan bubuk kayu pada beberapa sudut vitrin tempat koleksi dipamerkan dan pada koleksi

- Akrilik pendukung (informasi) ditemukan melengkung pada tititk tertentu.

Keadaan diatas merupakan suatu indikasi ada yang tidak wajar pada ruangan tempat koleksi itu berada. Diduga iklim ruangan sudah tidak mengakomodir koleksi dengan bahan tertentu, sehingga akhirnya tumbuh jamur. Munculnya bubuk kayu mengindikasi terdapat serangga yang aktif. Atas dasar hal tersebut, maka dilakukan pengambilan data iklim ruangan dengan menggunakan datalogger dengan jangka waktu tertentu. Sebagai pembanding, dilakukan pengambilan data iklim pada posisi yang sama, gedung pamer yang sama namun berada di lantai 2.

Posisi alat pada lantai 3 (terindikasi jamur dan serangga) ditempatkan pada 2 posisi, yaitu posisi ditengah ruangan (diletakkan dalam vitrin tengah) dan pinggir ruangan dekat foyer eskalator (didalam vitrin dipinggir) (Gambar 7).
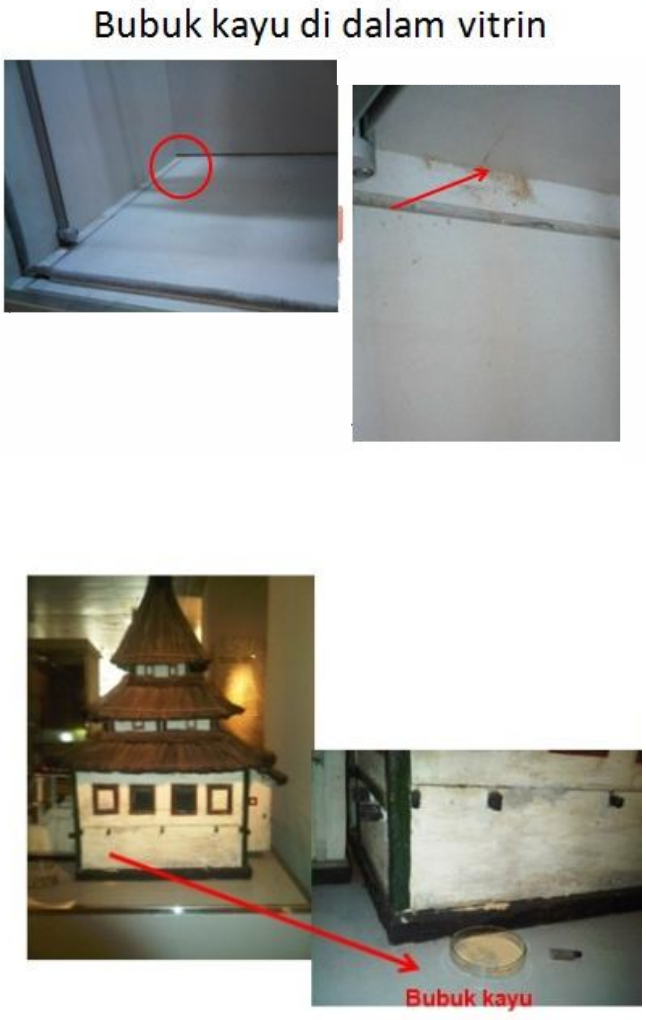

Gambar 5. Adanya bubuk kayu di sudut vitrin dan koleksi kayu (sumber foto: pribadi)

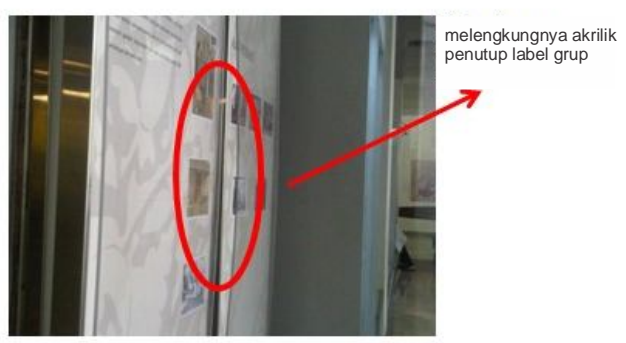

Gambar 6. Melengkungnya akrilik label informasi koleksi

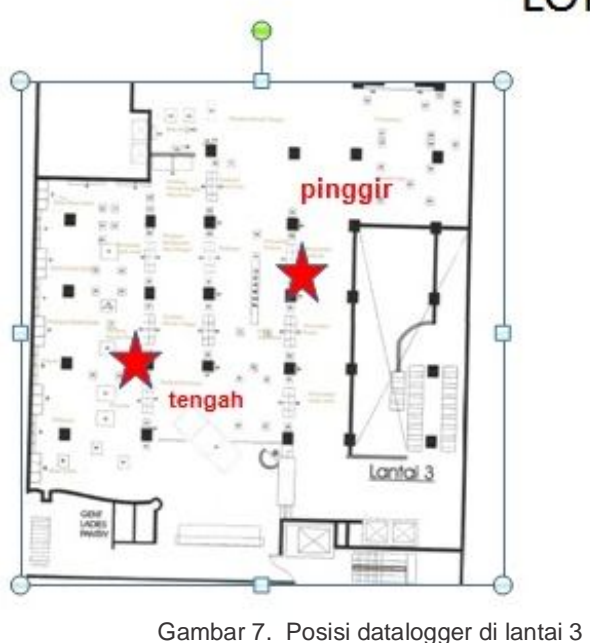


Hasil yang diperoleh :

\section{Vitrin tengah lantai 3}
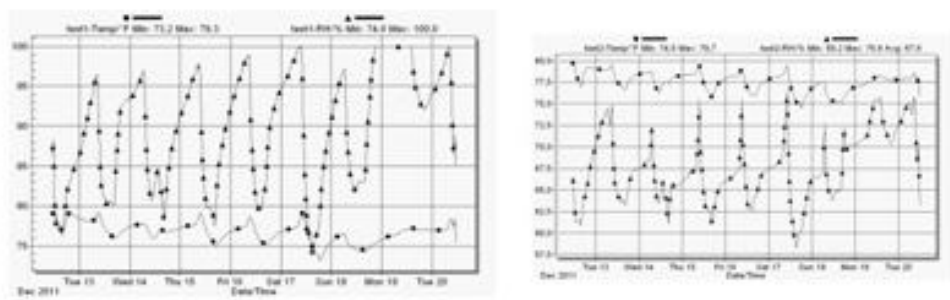

Gambar 8. Grafik $\mathrm{T}$ dan $\mathrm{RH}$ di lantai 3 pada daerah tengah dan pinggir

Vitrin pinggir lantai 3

\begin{tabular}{lll}
\hline LOKASI & Tmin-max (C) & RH min-max(\%) \\
\hline L3 tengah & $23,6-26,2$ & $74-100$ \\
\hline L3 pinggir & $23,6-26,5$ & $58,2-76,6$ \\
\hline
\end{tabular}

\section{LOKASI LANTAI 2}

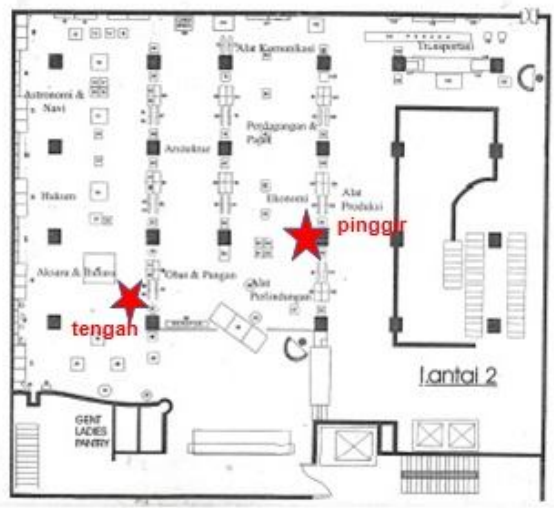

Gambar 9. Letak datalogger di lantai 2 menunjukkan lantai 3 lebih lembab dibandingkan dibandingkan lantai 2. Dan dengan membandingkan pola grafik diantara lantai 2 dan 3 , perbedaan $\mathrm{RH}$ pada siang dan malam tidak terlalu jauh di lantai 2, sehingga dapat dikatakan tidak terlalu fluktuatif. Oleh karena itu, tidak ditemukan jamur berkembang di lantai 2 .

RH yang fluktuatif sangat berperan dalam mendukung pertumbuhan jamur pada koleksi. Berdasarkan grafik diatas RH minimum yang diperoleh adalah 58\% dan 62\%. Nilai ini sudah masuk ke dalam range standar $\mathrm{RH}$ untuk semua jenis koleksi di museum. Thomson (2006) menyebutkan bahwa untuk daerah humid (lembab) dan tropis nilai $\mathrm{RH}$ yang mengakomodir semua jenis bahan koleksi adalah $62 \%$. Hal ini berarti diharapkan pada kelembaban tersebut tidak memicu tumbuhnya jamur atau menjadikan koleksi lembab. Namun kenyataannya berdasarkan data kajian yang diperoleh, nilai maksimum yang diperoleh sangat tinggi. Bahkan pada satu titik dapat mencapai hingga $100 \%$.

Fluktuasi yang sangat tinggi ini diperkirakan terjadi karena terjadi perbedaan iklim siang dan malam. Pada siang hari, AC dinyalakan, ruangan terkondisikan. Namun pada malam hari saat dimatikan kelembaban relatif ruangan berubah dengan cepat. Menurut Toledo (2007) yang diperlukan untuk iklim museum adalah tidak cukup hanya mencapai nilai standar namun juga menjaga agar nilai RH tetap, tidak berfluktuasi. Daerah yang lembab juga dapat menyebabkan koleksi kayu menjadi lebih lunak dan menjadi makanan empuk untuk serangga. Adanya bubuk kayu pada koleksi menandakan adanya serangga aktif di dalam. Hal ini jelas merugikan, karena koleksi

Hasil yang diperoleh
Vitrin tengah lantai 2

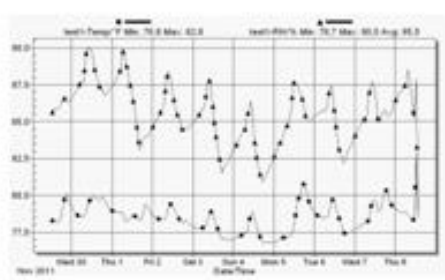

Vitrin pinggir lantai 2

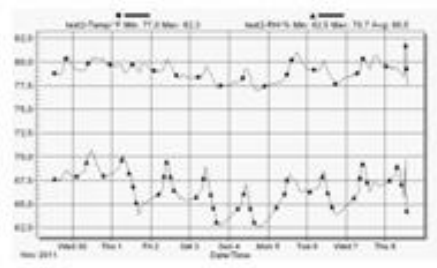

Gambar 10. Grafik T dan $\mathrm{RH}$ untuk lantai 2 pada posisi tengah dan pinggir

Hasil yang diperoleh pada pengukuran di lantai 2 adalah

\begin{tabular}{|lll|}
\hline LOKASI & Tmin-max (C) & Rh min-max(\%) \\
\hline L2 tengah & $24,89-28,2$ & $78,7-85,5$ \\
\hline L2 pinggir & $25-29,94$ & $62,5-79,7$ \\
\hline
\end{tabular}


akan semakin rapuh. Adanya fluktuasi yang sangat tinggi juga dipengaruhi tidak adanya udara yang bergerak. Jika dikembalikan kepada karakteristik gedung, pada gedung baru MNI, udara bergerak hanya ada di sekitar escalator. Udara bergerak terbanyak ada di lantai 1 karena pintu ruangan terbuka sehingga kemungkinan terdapat udara yang masuk dari luar gedung.

Jika dibandingkan dengan gedung lama (gedung A) sebelum revitalisasi, banyak ditemukan udara yang bergerak, dan beberapa ruangan masih terdapat ventilasi yang dilengkapi kipas angin, meski sudah ada yang dilengkapi AC. Sehingga tidak ditemukan koleksi berjamur di ruang pamer di ruang gedung $\mathrm{A}$.

Kondisi seperti ini harus segera diantisipasi dengan mengatur vitrin/showcase, sehingga berperan sebagai pengendali iklim pasif. Salah satu cara adalah dengan mengkondisikan ruangan dalam showcase sehingga $\mathrm{RH}$ didalamnya tidak fluktuatif.

Pengendalian RH dilakukan dengan meletakkan sejumlah silica gel yang telah dikondisikan dengan RH 5565\%. Dengan demikian silica gel berfungsi sebagai penyangga (buffer) RH selama koleksi dipamerkan. Keadaan ini telah dipraktekkan di Museum Nasional saat diadakan pameran Shared Culture Heritage antara MNI dan museum etnologi Leiden. Selama 3 bulan pameran yang diadakan di gedung $B$, ruangan di dalam vitrin tetap menunjukkan RH antara 55-65\% hingga pameran ditutup.

\section{Penutup}

Perubahan iklim pada koleksi museum dapat memicu timbulnya agen deteriorasi (penurunan mutu) yaitu temperatur dan kelembaban relatif (RH) yang tidak sesuai. Perubahan iklim yang dimaksud adalah perubahan dari lingkungan makro (luar) ke lingkungan mikro (dalam gedung), dan juga perubahan iklim dari satu gedung (ruangan) ke gedung (ruangan) yang lain. Gedung museum berfungsi sebagai pelindung, jika dapat mengakomodir iklim pasif. Namun seringkali gedung yang diperuntukkan untuk museum tidak dapat menjalankan perannya. Oleh karena itu, lingkungan mikro diperkecil ke ruangan dan ke vitrin. Lingkungan mikro adalah lingkungan yang dapat dikendalikan dan dikontrol, artinya lingkungan mikro yang melingkupi koleksi dapat mengatasi perbedaan iklim.

Dalam kegiatan relokasi koleksi, agar tidak terdapat perbedaan iklim, sebaiknya sebelum dilakukan relokasi, sudah diambil data iklim pada ruangan asal dan ruangan baru. Tujuannya adalah agar koleksi dapat segera beradaptasi dan mencapai keseimbangan dengan lingkungan baru. Sehingga tidak muncul deteriorasi pada koleksi. Keseimbangan iklim di dalam gedung museum bukan berarti mencapai nilai standar, namun menjaga kelembaban tetap stabil lebih diutamakan dengan menjaga tidak terjadi fluktuasi yang terlalu tinggi. Udara bergerak di dalam ruangan akan membantu menurunkan kelembaban, terutama saat AC dimatikan pada malam hari

Nilai yang tidak fluktuatif akan terlihat pada grafik yang tidak terlalu tajam pada hasil pembacaan data logger. Untuk memperoleh RH yang tetap selama waktu tertentu dapat diberikan silica gel yang berfungsi sebagai penyangga/buffer RH.

\section{Daftar Pustaka}

Grattan, D avid. 2011. Updated framework for the preservation of museum collections. Reflection on Conservation 2011. Canada : Canadian Conservation Institute.

Murdock, Cynthia . 2001. Museum Handbook, part 1, appendix I. National Park Service. Washington DC : Museum Management Program.

Padfield, Tim. 2008. Exploring the limits for Passive Indoor Climate Control., www.padfield.org/ tim/ cfys/ . O ktober 2008.

Pedersoli Jr, Jose Luiz. 2007. ICCRO M SPAFA CollAsia 2010 International course, Scientific and traditional Method in Conservation. Vientiane.

Seksi Konservasi dan Restorasi., Bidang Konservasi dan Penyajian. 2012. Kajian Silica Gel dalam rangka pameran Share Culture Heritage, Laporan kegiatan.

Seksi Konservasi dan Restorasi. 2012. Kajian Awal Iklim Mikro di gedung baru. Laporan kegiatan . 
Thomson, Gary. 2006. The Museum Environment 2nd edition. Butterworth, Heinnemann.

Toledo, Fransiza. 2007. Museum Passive Buildings in Warm, Humid Climates. Contribution to the Experts's Roundtable on Suistainable Climate Management Strategies. Spanyol.
Yulita, Ita. 2008. Konservasi Preventif di Museum. Museografia Vol II No 2 O ktober 2008. Direktorat Museum, D epartemen Kebudayaan dan Pariwisata. 